\title{
PESAN BUDAYA DALAM TUTURAN KADA TOMINAA DI KABUPATEN TANA TORAJA
}

\author{
Anastasia Baan \\ FKIP Universitas Kristen Indonesia Toraja \\ email: alfanrotiranda@gmail.com
}

\begin{abstract}
Abstrak
Penelitian ini bertujuan mendeskripsikan isi dan fungsi pesan dalam tuturan kada tominaa di Kabupaten Tana Toraja. Penelitian ini merupakan penelitian kualitatif dengan pendekatan hermeneutika. Pengumpulan data dilakukan melalui wawancara, studi dokumen, dan pengamatan. Analisis data dilakukan secara kualitatif dengan model interaktif. Hasil penelitian sebagai berikut. Pertama, isi pesan dalam tuturan kada tominaa, yakni: (a) tradisi budaya masyarakat daerah Tana Toraja; (b) hubungan sosial kemasyarakatan daerah Tana Toraja, meliputi hubungan saling mencintai antaranggota keluarga dan saling peduli antaranggota masyarakat; dan (c) pekerjaan atau mata pencaharian masyarakat daerah Tana Toraja. Kedua, fungsi pesan dalam tuturan kada tominaa, yakni: (a) fungsi pesan tindak ekspresif, berupa meminta maaf dan mengungkapkan perasaan; dan (b) fungsi pesan tindak direktif, berupa harapan dan nasihat.
\end{abstract}

Kata kunci: isi pesan, fungsi pesan, tindak ekspresif, tindak direktif

\section{CULTURAL MESSAGES IN THE KADA TOMINAA NARRATION IN TANA TORAJA REGENCY}

\begin{abstract}
This study aims to describe the contents and functions of messages in the kada tominaa narration in Tana Toraja Regency. This was a qualitative study employing the hermeneutic approach. The data were collected through interviews, document studies, and observations. They were qualitatively analyzed using the interactive model. The results of the study are as follows. First, the contents of messages in the kada tominaa narration include: (a) the cultural traditions of the community in the Tana Toraja area; (b) the social relationship in the Tana Toraja area, i.e. a relationship of mutual love among family members and that of mutual care among community members; and (c) jobs and livelihoods of the community in the Tana Toraja area. Second, the functions of messages in the kada tominaa narration include: (a) expressive acts for apologies and expressions of feelings, and (b) directive acts for expectation and advice.
\end{abstract}

Keywords: message contents, message functions, expressive acts, directive acts

\section{PENDAHULUAN}

Kada tominaa yang menjadi tradisi dan masih berkembang di daerah Tana Toraja merupakan salah satu sastra lisan. Tradisi tersebut berwujud tuturan yang diwariskan turun-temurun secara lisan di daerah Tana Toraja. Kada tominaa daerah Tana Toraja dituturkan oleh pemangku adat atau sekelompok orang dalam setiap adat upacara pemakaman di daerah Tana Toraja atau yang disebut rambu solo. Pada upacara pemakaman tersebut, kada tominaa 
biasanya dituturkan pada kegiatan singgi, badong, dan bating. Pada kegiatan singgi, kada tominaa dituturkan oleh seorang pemangku adat untuk menyampaikan pujian kepada si jenazah. Pada kegiatan badong, kada tominaa dituturkan oleh sekelompok orang dengan membuat lingkaran dan saling bergandengan tangan, sedangkan pada kegiatan bating, kada tominaa dituturkan secara bergantian oleh seorang lelaki dan perempuan dan biasanya diiringi musik seruling. Upacara pemakaman atau yang disebut rambu solo' merupakan bentuk penghargaan anak kepada orang tuanya yang dilaksanakan pada sore hari saat matahari mulai condong ke barat dan biasanya berlangsung tiga hari sampai seminggu (Sikki, 1986).

Kada tominaa juga sebagai adat yang dituturkan pada berbagai kegiatan upacara syukuran atau yang disebut rambu tuka', misalnya pada acara pernikahan atau yang disebut rampanan $k a p a^{\prime}$, dan acara syukuran rumah adat, atau yang disebut mangrara tongkonan. Pelaksanaan upacara syukuran atau yang disebut rambu tuka' dilaksanakan pada pagi hari, yaitu sebelum matahari condong ke barat, dan biasanya diadakan hanya sehari.

Sebagai sastra lisan, kada tominaa daerah Tana Toraja memiliki kekhasan sendiri. Kekhasannya adalah pada ekspresi yang disesuaikan dengan kepentingan-kepentingan tertentu sesuai bunyi syair tersebut. Hal ini berarti kada tominaa daerah Tana Toraja dijadikan sebagai salah satu media ekspresi masyarakat daerah Tana Toraja untuk mengomunikasikan pengalaman hidupnya ataupun kepentingan tertentu kepada sesamanya dalam lingkup masyarakat daerah Toraja. Saryono (2006:11) berpendapat bahwa tidak mungkin terjadi komunikasi tanpa tutur, dan tidak mungkin terbentuk jaringan sosial untuk melaksanakan kehidupan bersama tanpa tutur. Dengan demikian, dapat dikatakan bahwa kada tominaa sebagai tradisi masyarakat daerah Tana Toraja merupakan kekayaan budaya yang perlu dipertahankan agar tidak mengalami kepunahan.

Sejalan dengan paparan di atas, Suyitno (2010) mengungkapkan bahwa sebagai ekspresi budaya, wacana budaya - termasuk tuturan kada tominaa daerah Tana Toraja - memiliki fungsi sebagai identitas budaya masyarakat daerah Tana Toraja. Tuturan kada tominaa daerah Tana Toraja dipandang identik dengan sifat dan perilaku masyarakat daerah Tana Toraja. Sebagai media komunikasi yang mengandung pesan-pesan berupa nasihat, kada tominaa daerah TanaToraja berwujud tuturan. Kada tominaa daerah Tana Toraja pada umumnya dituturkan dengan menggunakan metafora. Fenomena metafora dalam kada tominaa terlihat dari penggunaan kata-kata kiasan berupa perlambangan dan perumpamaan yang harus dimaknai secara metaforis, misalnya perlambangan suatu keadaan atau sifat seseorang dengan sesuatu yang lain.

Dalam berpikir dan menciptakan metafora, manusia tidak dapat melepaskan diri dari lingkungannya, karena ia selalu mengadakan interaksi dengan lingkungannya itu. Wahab (1991:76) berpendapat bahwa studi tentang interaksi antara manusia dengan lingkungannya (makhluk bernyawa maupun benda tak bernyawa) itu disebut studi tentang sistem ekologi. Dengan sendirinya, keadaan sistem ekologi suatu kelompok masyarakat akan tercermin dalam penggunaan metafora yang diciptakan oleh kelompok masyarakat itu. Sistem ekologi persepsi manusia tersusun dalam suatu hierarki yang sangat teratur. Dengan demikian, ruang persepsi manusia yang mempengaruhi penciptaan metafora pada kalangan penyair dan sastrawan juga tersusun menurut hierarki yang teratur pula yakni: being, cosmos, energy, substantial, object, living, animate, human. Hirarki persepsi manusia tersebut dimulai dari manusia sendiri, karena manusia dengan segala macam tingkah 
lakunya merupakan lingkungan manusia yang terdekat.

Bagi masyarakat daerah Tana Toraja, keberadaan kada tominaa merupakan kekayaan budaya yang mencerminkan kehidupan masyarakatnya. Dengan demikian, bagi masyarakat daerah Tana Toraja, tradisi budaya tersebut merupakan unsur yang sangat dekat dengan perilaku kehidupannya. Sebagai pengembangan nilai budaya dalam rambu solo' dan rambu tuka', terdapat ungkapan-ungkapan bahasa yang sangat sarat dengan nasihat. Nasihat tersebut disampaikan baik secara eksplisit maupun secara implisit. Penyampaian secara implisit, berarti tuturan yang digunakan banyak menggunakan tuturan berupa kiasan, perlambangan, perbandingan dan perumpamaan. Untuk memahami maksud yang disampaikan, seseorang harus mampu menginterpretasikan tuturan tersebut yang didasari oleh pengetahuan tentang budaya daerah Tana Toraja.

Berdasarkan paparan di atas, dapat dikatakan bahwa kada tominaa, khususnya yang berkaitan dengan metafor-metafor yang ada di dalamnya, dapat dimanfaatkan sebagai materi pembelajaran untuk pendidikan karakter bagi masyarakat Tana Toraja. Mutu karakter seseorang atau manusia dapat menentukan martabat dan adab seorang manusia; mutu karakter sebuah bangsa akan menentukan martabat dan adab sebuah bangsa tersebut. Jika seorang atau sekelompok manusia memiliki mutu karakter yang kuat, mereka akan menjadi manusia bermartabat dan beradab. Sebaliknya, jika seorang atau sekelompok manusia memiliki mutu karakter, mereka dianggap tidak atau kurang bermartabat dan beradab. Manusia bermartabat dan beradab adalah seorang atau sekelompok manusia yang disegani, dihormati, dijunjung, diperhitungkan, dan diakui keberadaannya oleh pihak lain atau manusia lain.
Tuturan kada tominaa adalah bentuk dari sastra lisan yang mengekspresikan dan mengungkapkan pikiran, perasaan, dan pengalaman budaya penuturnya. Ini berarti bahwa ekspresi metaforis dalam tuturan kada tominaa berfungsi sebagai sarana ekspresi bagi masyarakat atau komunitas penuturnya dalam rangka memenuhi kebutuhan sosial budaya dan tuntutan lingkungannya. Oleh karena itu, tuturan kada tominaa sebagai sarana ekspresi memiliki hubungan ciri dengan hal yang diekspresikannya. Hal itu sejalan dengan pendapat Suyitno (2010:29) yang mengatakan bahwa melalui ekspresi budaya dalam tuturan, dapat dipahami budaya penuturnya. Sejalan dengan pernyataan tersebut, Ahimsya sebagaimana dikutip oleh Pamungkas (2012:115) mengatakan bahwa sebagai suatu bentuk ekspresi budaya masyarakat pemiliknya, sastra lisan tidak hanya mengandung unsur keindahan (estetik), tetapi juga mengandung berbagai informasi nilai-nilai kebudayaan tradisi yang bersangkutan. Oleh karena itu, sebagai salah satu data budaya sastra lisan, kada tominaa dapat dianggap sebagai pintu untuk memahami salah satu atau mungkin keseluruhan unsur kebudayaan yang bersangkutan. Untuk memahami pesan-pesan yang diekspresikan secara metaforis dalam tuturan kada tominaa, diperlukan pemahaman tentang ragam isi pesan dan fungsi pesan yang diekspresikan dalam kada tominaa.

\section{METODE}

Penelitian ini termasuk penelitian kualitatif. Penelitian ini menggunakan latar alamiah, yakni pada masyarakat di daerah Tana Toraja dengan datanya berupa katakata dan bukan angka-angka. Penarikan simpulan dilakukan secara induktif dan bersifat emik (Bogdan \& Biklen, 1990) Pendekatan yang digunakan dalam penelitian ini adalah pendekatan hermeneutika dalam pandangan Ricoeur, yakni pemahaman pada: (a) tahap semantik, (b) 
tahap refleksif, dan (c) tahap eksistensial (Sumaryono, 1995). Dalam konteks hermeneutika, tuturan kada tominaa daerah Tana Toraja dipandang sebagai cerminan kehidupan masyarakat daerah Tana Toraja sehingga pesan yang terkandung dan terungkap dalam tuturan kada tominaa daerah Tana Toraja merupakan gambaran budaya masyarakat daerah Tana Toraja.

Data penelitian ini berupa tuturan kada tominaa daerah Tana Toraja. Data ini dikelompokkan dalam dua kategori. Pertama, tuturan kada tominaa pada kegiatan rambu tuka', yaitu kegiatan yang berhubungan dengan syukuran masyarakat daerah Tana Toraja. Kegiatan yang dimaksud adalah syukuran pernikahan atau yang disebut rampanan kapa dan syukuran rumah atau yang disebut mangrara tongkonan. Kedua, tuturan kada tominaa pada kegiatan rambu solo', yakni kegiatan yang berhubungan dengan upacara pemakaman masyarakat daerah Tana Toraja.

Selain berupa tuturan kada tominaa, data penelitian ini juga berupa informasi tentang tradisi budaya. Data-data tersebut dimanfaatkan untuk memperkuat dan mempertajam penafsiran makna yang berkaitan dengan fokus masalah yang diteliti. Data yang telah disebutkan di atas berasal dari beberapa sumber, yakni dokumen, catatan wawancara dengan informan, dan catatan observasi tentang aktivitas masyarakat Tana Toraja. Berdasarkan sumber data tersebut, pengumpulan data dilakukan melalui wawancara, studi dokumen, dan pengamatan.

Analisis data dilakukan sejak awal pengumpulan data dan dilakukan secara interaktif. Saat mengumpulkan data, peneliti melakukan reduksi data, penyajian data, dan penarikan simpulan. Demikian seterusnya, dilakukan secara berulangulang sampai diperoleh simpulan yang benar-benar memadai. Penafsiran hasil penelitian menggunakan pendekatan hermeneutika, yaitu pemahaman (verste- hen) secara cermat melalui tahap semantik, tahap refleksif, dan tahap eksistensial (Ricouer, 2003). Pada level semantik, dilakukan pembacaan dan pemahaman tuturan lagu secara cermat dengan cara mengidentifikasi data, mengklasifikasi data, dan mengkategorisasi data sesuai dengan permasalahan dalam penelitian ini. Pada level refleksif, dilakukan penggayutan data temuan dari tuturan kada tominaa dengan perilaku budaya, tradisi budaya, dan lingkungan sosial budaya masyarakatnya. Kemudian, pada level eksistensi, dilakukan penafsiran makna data dengan melibatkan seluruh informasi yang menghasilkan temuan holistik emik.

\section{HASIL DAN PEMBAHASAN}

Tuturan kada tominaa daerah Tana Toraja merupakan cerminan kebudayaan masyarakat daerah Tana Toraja dalam kehidupan sehari-hari. Tuturan kada tominaa berbentuk tuturan yang khas sesuai dengan ekologi dan budaya masyarakat daerah Tana Toraja yang menjadi kebiasaan dalam menjalani kehidupan seharihari. Karena itu, tuturan Kada tominaa mengandung pesan budaya. Berdasarkan temuan penelitian, tuturan dalam Kada tominaa dapat dicermati berdasarkan isi pesan dan fungsi pesan, sebagaimana dipaparkan berikut ini.

\section{Isi Pesan Kada Tominaa}

Tuturan kada tominaa sebagai cerminan kebudayaan masyarakat daerah Tana Toraja mengandung pesan-pesan budaya bagi kehidupan masyarakat daerah Tana Toraja. Pesan-pesan tersebut mengungkapkan nilai-nilai luhur yang harus ditaati dan dihormati oleh masyarakat daerah Tana Toraja dalam menjalani aktivitas sosial budaya. Isi pesan dalam tuturan kada tominaa daerah Tana Toraja dapat dikategorisasikan menjadi tiga ranah, yakni (a) tradisi budaya masyarakat daerah Tana Toraja, (b) hubungan sosial kemasyarakatan daerah Tana Toraja, dan (c) pekerjaan 
atau mata pencaharian masyarakat daerah Tana Toraja.

\section{Tradisi Budaya Masyarakat Tana Toraja}

Masyarakat daerah Tana Toraja memiliki tradisi budaya yang bercirikan khas daerah Tana Toraja. Tradisi budaya yang dimaksud adalah upacara adat berupa syukuran atau yang disebut rambu tuka', dan pemakaman yang disebut rambu solo'. Tuturan kada tominaa yang memuat tradisi masyarakat daerah Tana Toraja terekam pada kegiatan singgi berikut ini.

Natole /tumangke suru '/Tumetang / passara'kasan/Suru'na rampanan kapa'I Sola passulean allo

(Sekali lagi ia/menyembah Tuhan/Melakukan/pemujaan/Beribadah dalam setiap rumah tangga/Bersama bergantinya hari)

Tuturan tumangke suru' bermakna 'menyembah Tuhan' sedangkan tuturan passara'kasan bermakna 'pemujaan'. Tuturan tumangke suru' dan passara'kasan memberi pesan bahwa pada masyarakat daerah Tana Toraja, dalam satu rumah tangga selalu mengadakan hubungan dengan Tuhan melalui ibadah syukuran atas segala pemberian Tuhan. Syukuran itu berupa syukuran panen, syukuran rumah, syukuran kelahiran seorang anak, syukuran sembuh dari penyakit. Dengan syukuran tersebut diharapkan berkat-berkat Tuhan selalu mengalir di dalam kehidupan manusia. Penggunaan tuturan tumangke suru' dan passara'kasan dalam kada tominaa tersebut menyampaikan pesan tentang tradisi budaya masyarakat daerah Tana Toraja.

Selain tradisi syukuran, juga terekam tradisi masyarakat Tana Toraja dalam pemakaman yang disebut rambu solo'. Salah satu kegiatan yang dilakukan oleh masyarakat daerah Tana Toraja dalam tradisi rambu solo'seperti yang terekam dalam tuturan kada tominaa pada data berikut ini.

\begin{abstract}
/Bendan tau-tau nangka'/Sola tobombo dikita//Lolongmi rante kalua'.Tama tandung kalonaran
\end{abstract}

(/Berdirilah patung kayu nangka/ Gambar arwah yang kelihatan//Mengalirlah manusia di pelataran luas/ Masuk di halaman duka)

Tuturan bendan tau-tau nangka' bermakna 'berdirilah patung kayu nangka' dan tuturan lolongmi rante kalua bermakna 'mengalirlah manusia di pelataran luas'. Tuturan bendan tau-tau nangka' dan lolongmi rante kalua tersebut memberi pesan bahwa jika patung kayu nangka yang dibuat menyerupai wajah jenasah telah diletakkan di pelataran duka, itu menandakan bahwa orang yang meninggal tersebut akan segera dimulai dilaksanakan upacara pemakamannya. Dengan demikian, orang-orang yang berada di sekeliling kampung, keluarga, ataupun kerabat yang ada di perantauan akan segera berdatangan di rumah duka dengan membawa beberapa ekor babi atau kerbau untuk disumbangkan kepada keluarga yang sedang berduka sebagai tanda turut berduka cita sebagai tanda hormat kepada yang telah meninggal. Tuturan kada tominaa tersebut menggambarkan bahwa masyarakat daerah Tana Toraja sangat mengutamakan rasa kebersamaan dan kepedulian terhadap sesamanya yang mengalami kedukaan. Rasa kebersamaan itu sangat membantu bagi keluarga yang sedang berduka, karena jika tradisi rambu solo' itu dilaksanakan sangat membutuhkan biaya yang banyak, mulai dari harga ratusan juta hingga milyaran. Tuturan bendan tau-tau nangka' dan lolongmi rante kalua memberi pesan tentang tradisi budaya masyarakat daerah Tana Toraja.

Paparan di atas menunjukkan bahwa tradisi budaya masyarakat daerah Tana Toraja merupakan tradisi kepercayaan masyarakat daerah Tana Toraja yang diwariskan oleh leluhurnya. Pada saat ini, sebagian besar masyarakat daerah 
Tana Toraja telah menganut salah satu agama, tetapi masyarakat di daerah tersebut masih mempercayai dan tetap menjalankan tradisi leluhurnya. Misalnya (a) tradisi syukuran atau yang disebut rambu tuka', berupa syukuran pernikahan, syukuran panen, syukuran rumah, dan sebagainya, (b) tradisi upacara pemakaman atau yang disebut rambu solo'. Tradisi yang dimaksud misalnya pada tuturan kada tominaa lando longa 'rumah adat'. Kata lando longa bermakna 'rumah adat daerah Tana Toraja yang atapnya memanjang'. Bagi masyarakat daerah Tana Toraja, rumah adat tersebut berfungsi sebagai tempat menyatunya seluruh rumpun keluarga untuk melakukan berbagai tradisi masyarakat daerah Tana Toraja. Adams (2006:73) mengatakan bahwa pesan yang mendasari adanya tongkonan di daerah Toraja adalah agar terjalin hubungan yang harmonis di antara masyarakat Toraja.

Selanjutnya, terdapat juga tuturan kada tominaa yang menyebutkan kinallo yang bermakna 'bekal'. Masyarakat daerah Tana Toraja menjadikan tradisi dan kepercayaan bahwa 'bekal' berfungsi untuk mengantarkan arwah orang yang telah meninggal menuju surga yang disebut puya dalam bahasa Toraja. Pada jaman dahulu 'bekal' yang dimaksud tersebut adalah jumlah kerbau yang dikurbankan saat pelaksanaan upacara adat pemakaman jenasah, yakni semakin banyak kerbau yang dikurbankan maka semakin cepat arwah jenasah tersebut menuju surga. Tradisi penyembelihan kerbau saat upacara pemakaman juga difungsikan untuk menjamu orang yang datang di pelataran duka. Selain itu, pemotongan kerbau secara besar-besaran hingga kadang mencapai milyaran menjadi suatu kehormatan bagi keluarga yang melaksanakannya, karena kerbau bagi masyarakat Tana Toraja adalah harta yang sangat berharga.

\section{Hubungan Sosial Kemasyarakatan Dae- rah Tana Toraja}

Tuturan kada tominaa darah Tana Toraja juga berisi pesan-pesan budaya yang berkaitan dengan masalah hubungan sosial kemasyarakatan. Hubungan sosial tersebut terjadi akibat adanya komunikasi antarindividu dalam memenuhi tuntutan kehidupan di masyarakat. Pesan budaya tersebut dapat dikelompokkan menjadi: (a) hubungan saling mencintai antaranggota keluarga, dan (b) hubungan saling peduli antarmasyarakat. Kedua pesan tersebut terdapat pada tuturan kada tominaa daerah Tana Toraja.

Hubungan saling mencintai antarkeluarga adalah bentuk cinta kasih anak kepada ayahnya. Hubungan cinta kasih tersebut dapat ditemukan dalam tuturan kada tominaa pada kegiatan badong berikut ini.

Ambe' perangikan mati'/Ambe' tanding talingakan/Angki/loloan rara'ko/Angki /tendeng bulaanko/Angki/gente' kandaurko/

(Ayah dengarkan kami/Ayah dengarkan kami/Kami akan /memujimu/ Kami akan /memujamu/Kami akan / membanggakanmu)

Tuturan loloan rara'ko bermakna 'memujimu', tuturan tendeng bulaanko bermakna 'memujamu, sedangkan tuturan gente' kandaurko bermakna 'membanggakanmu'. Tuturan loloan rara'ko, tendeng bulaanko, gente' kandaurko menyampaikan pesan tentang bentuk terima kasih seorang anak kepada orang tuanya yang sangat dibanggakan anak-anaknya karena telah merawat dan mendidik mereka hingga dewasa dengan penuh kasih sayang yang tulus sampai mereka mendapat pekerjaan. Rasa terima kasih tersebut diwujudkan dalam bentuk sebuah penghargaan yaitu berupa upa-cara pemakaman yang disertai pemotongan kerbau dan babi secara besarbesaran yakni sekitar 50 sampai 100 ekor kerbau. Tradisi pemakaman di daerah 
Tana Toraja bagi masyarakat yang mampu atau kaya, biasanya berlangsung seminggu setelah hari kematian jenasah. Namun, bagi orang yang kurang mampu, kadangkadang pemakaman jenasah dilaksanakan setelah berbulan-bulan bahkan bertahuntahun sejak hari kematian jenasah. Hal itu dilakukan dengan tujuan agar keluarga dapat mengumpulkan uang untuk membiayai upacara pemakaman tersebut. Untuk itu, agar jenasah bisa bertahan lama, jenasah itu diawetkan dengan menggunakan formalin kemudian dibungkus kain hingga berlapis-lapis atau ada juga yang menggunakan peti. Jenasah tersebut lalu diletakkan di sebuah rumah tongkonan sesuai kesepakatan keluarga. Selama disimpan, jenasah itu tetap dianggap masih hidup. Oleh karena itu, jenasah tersebut diperlakukan selayaknya orang yang sedang sakit, yakni diajak bicara, diberi makan, ditemani tidur, dan sebagainya. Tuturan loloan rara'ko, tendeng bulaanko, gente' kandaurko memberi pesan tentang hubungan saling mencintai antaranggota keluarga.

Selain hubungan cinta kasih anak kepada orang tua, juga terdapat hubungan cinta kasih orang tua kepada anaknya. Hubungan tersebut tercermin pada kegiatan bating dalam tuturan kada tominaa berikut ini.

Inde indo' ma'dadinna/Sola toma'/kaboro'/nalAnna toma'/kamaya/nna

(Ini ibu yang melahirkannya/Yang/menyanyangi/nya/Yang/merawat/nya)

Tuturan kaboro bermakna 'menyayangi' dan tuturan kamaya bermakna 'merawat'. Tuturan kaboro' dan kamaya menyampaikan pesan bahwa begitu besar cinta kasih seorang ibu kepada anaknya, serta merawat anaknya dengan tulus,mulai dari kandungan ibu hingga dewasa. Tuturan kaboro' dan kamaya memberi pesan tentang hubungan saling mencintai antaranggota keluarga. Hubungan saling peduli antar- masyarakat di daerah Tana Toraja sangat tampak pada kegiatan upacara adat pemakaman rambu solo'. Hubungan tersebut dapat dicermati dalam tuturan kada tominaa pada kegiatan bating berikut ini.

Bendan tau-tau nangka/Sola tobombo dikita//Lolongmi rante kalua'//Tama tandung kalonaran/

(Berdirilah patung kayu nangka,/ Gambar arwah yang kelihatan//Mengalirlah manusia di pelataran luas/ Masuk di halaman duka)

Tuturan lolongmi rante kalua' bermakna 'mengalirlah manusia di pelataran duka' dan tuturan tama tandung kalonaranbermakna 'masuk di halaman duka'. Tuturan lolongmi rante kalua'dan tama tandung kalonaran memberi pesan tentang bentuk saling kepedulian antarmasyarakat di daerah Tana Toraja dalam hal kedukaan. Jika ada orang yang mengalami kedukaan, semua tetangga atau keluarga dekat maupun keluarga jauh segera berbondong-bondong menuju tempat duka itu. Selanjutnya, jika sudah tiba waktunya hendak dimakamkan, para tetangga dan keluarga segera berdatangan menyumbangkan tenaga, ternak, dan sebagainya kepada keluarga yang mengalami kedukaan. Tuturan lolongmi rante kalua'dan tama tandung kalonaran dalam kada tominaa tersebut memberi pesan tentang hubungan saling peduli antarmasyarakat. Hubungan kepedulian antarmasyarakat juga tercermin dalam tuturan kada tominaa pada kegiatan bating berikut ini.

Petawa manda nabenki'/Sola kadisidisian/To/tang merremme' rakka'na// Tang mennoton tarunonal

(Tawanya yang dia berikan/Dan senyumannya/Orang yang /tidak bertumpang tangan/Orang yang/tidak lepas tangan)

Tuturan tang merremme' rakka'na, bermakna'tidak bertumpang tangan' dan 
tuturan tang me-nnoton tarunona bermakna 'tidak lepas tangan'. Tuturan tang merremme' rakka'na, dan tang mennoton tarunona menyampaikan pesan untuk selalu menerapkan sikap tolong menolong kepada sesama manusia. Hal tersebut sesuai dengan falsafah masyarakat daerah Tana Toraja yaitu misa kada dipotuo, pantan kada dipomate yang artinya bersatu kita teguh bercerai kita runtuh. Sikap tersebut sangat ditekankan oleh para orang tua kepada anak-anaknya untuk menciptakan rasa persatuan dan kebersamaan. Tuturan tang merremme' rakka'na dan tang mennoton tarunona memberi pesan tentang hubungan saling peduli antarmasyarakat.

Berdasarkan paparan di atas, dapat dikemukakan bahwa ada dua pesan yang disampaikan tentang hubungan sosial kemasyarakatan daerah Tana Toraja, yaitu pesan tentang: (a) hubungan saling mencintai antaranggota keluarga dan (b) hubungan saling peduli antarmasyarakat. Hubungan saling mencintai antaranggota keluarga yang mengungkapkan nasihat tentang cinta kasih orang tua kepada anaknya, ditandai dengan ketulusan orang tua dalam merawat dan membim-bing anak-anaknya. Sementara, cinta kasih anak kepada orang tuanya ditandai oleh ungkapan rasa syukur anak kepada orang tuanya, misalnya merawat orang tuanya yang sudah lanjut usia, serta melengkapi upacara adat pemakaman jika orang tua sudah meninggal. Hubungan saling peduli antarmasyarakat mengungkapkan nasihat tentang sikap yang ramah dan suka tolong-menolong antar sesama. Sikap tesebut diberikan kepada semua orang tanpa membeda-bedakannya.

Dari paparan di atas, tergambar bahwa manusia selalu berada dalam dimensi kemasyarakatan. Sebagai makhluk sosial, mereka hidup bersama di dalam masyarakat dan mereka memiliki tanggung jawab untuk saling memahami antara yang satu dengan yang lainnya. Kebebasan mereka dibatasi oleh kebe- basan orang lain. Mereka terikat oleh nilai-nilai, norma-norma, hukum, dan aturan yang berlaku dan melandasi hidup mereka di masyarakat. Mereka juga dituntut untuk memiliki jiwa "kewiraan" yang meliputi unsur-unsur keberanian, kejujuran, kedisiplinan, dan tanggung jawab. Tanpa adanya sikap itu, mereka akan hidup terpencil dalam kehidupannya di masyarakat sehingga sulit untuk mengembangkan potensi dirinya.

Dalam pandangan Snijders (2004:143), sikap setiap individu manusia dalam hu-bungannya dengan dirinya, sesamanya, dan alam merupakan hubungan yang bersifat seruan sekaligus paradoks. Hubungan dengan sesamanya mengarah pada satu kesatuan, tetapi setiap individu dalam kesatuan hubungan tersebut mengarah pada keunikan dirinya yang sebenarnya. Dalam hubungannya dengan alam, manusia menjadi diri dengan memanusiakan alam. Selanjutnya, sebagai makhuk yang berbudaya, manusia mengaku dirinya sebagai makhluk yang beragama. Dimensi religius ini bersumber dari diri manusia masing-masing dan menjadi bahan refleksi juga untuk memperdalam paham tentang diri manusia itu sendiri. Dalam refleksi atas paham atas penghayatan relegius, manusia menemukan dirinya terarah kepada Tuhan.

Sikap seseorang dalam kehidupan di masyarakat dilandasi dan diarahkan oleh pandangan hidupnya. Koentjaraningrat (1981) menjelaskan bahwa pandangan hidup adalah nilai-nilai yang dianut oleh masyarakat yang dipilih secara selektif oleh para individu dan golongan di dalam masyarakat. Pandangan hidup ini berfungsi sebagai tata kelakuan yang mengatur, mengedali, dan memberi arah kepada tata kelakukan dan perbuatan manusia dalam masyarakat. Seluruh dari tata kelakuan manusia itu berpola menjadi suatu pranata yang dapat dirinci menurut fungsi-fungsi khasnya dalam masyarakatnya. 
Pada masyarakat Tana Toraja terdapat suatu pranata-pranata, baik dalam hubungan dengan Tuhan maupun hubungan manusia dengan manusia/sesamanya. Pranata-pranata ini memiliki dasar konsep dan pedoman hidup dalam sistem nilai yang kuat yang sejak dulu (nenek moyangnya) ada dan turun-temurun sampai sekarang. Dalam pandangan Daldjoeni dan Suyitno (1986), relasi antara manusia dengan sesamanya, manusia dengan Tuhan merupakan etika lingkungan. Unsurunsur itu saling mengait dan merupakan satu kesatuan yang tidak dapat diabaikan salah satu unsurnya. Setiap masyarakat memiliki etika lingkungan yang berbedabeda mengacu pada budaya yang berlaku di daerah tempat mereka tinggal.

\section{Mata Pencaharian Masyarakat Daerah Tana Toraja}

Pekerjaan atau mata pencaharian merupakan salah satu unsur budaya masyarakat daerah Tana Toraja. Sebagai unsur budaya, mata pencaharian masyarakat beraneka ragam. Masyarakat yang bermatapencaharian sebagai petani memiliki pola dan perilaku yang berbeda dengan masyarakat yang bermatapencaharian sebagai peternak atau buruh tukang serta pegawai negeri. Karena itu, pesan yang disampaikan oleh masyarakat juga berbeda. Pesan budaya masyarakat Tana Toraja yang berkaitan dengan mata pencaharian tersebut juga terdapat dalam tuturan kada tominaa daerah Tana Toraja. Tuturan yang dimaksud tersebut dapat dicermati pada kegiatan singgi berikut ini.

Suru'na /tengko tiranduk/Sola /ayoka panoto/Ma'doke-doke rangka'nal $M a^{\prime}$ passoan tarunona/Sitondon tindo bonginna sola mamma' karoenna

(Ibadah /mengolah tanah/Upacara / menanam bajak/Jari-jarinya bagaikan tombak/Jemarinya setajam linggis/ Jadilah sesuai mimpi-mimpi dalam tidurnya)
Tuturan tengko tiranduk tersebut bermakna 'mengolah tanah' dan tuturan ayoka panoto bermakna 'menanam bajak'. Tuturan tengko tiranduk dan ayoka panoto tersebut menggambarkan bahwa masyarakat daerah Tana Toraja pada umumnya bermatapencaharian sebagai petani yang tekun bekerja mengolah tanah untuk memenuhi kebutuhan hidupnya, sehingga apa yang dicita-citakan tercapai juga. Semua itu diperolehnya berkat doa dan kerja kerasnya. Bagi masyarakat daerah Tana Toraja, tuturan kada tominaa tersebut menyampaikan pesan bahwa jika kita ingin hidup sukses, kita harus tekun bekerja dan tak lupa selalu mengucap syukur kepada Tuhan. Tuturan tengko tiranduk dan ayoka panoto dalam kada tominaa tersebut memberi pesan tentang pekerjaan atau mata pencaharian masyarakat daerah Tana Toraja.

Pesan yang juga berkaitan dengan mata pencaharian sebagai petani terungkap pula pada data berikut ini.

/Kalimbaun ma'pagu'gu/Batu napaturu-turu/kenabandan pekali/Kenasalaga rakkai/Kenatengko tarunoi

(/Tanah besar dibukanya//Bebatuan dipecahkannya/ dengan linggis/ Digaruk dengan jari-jarinya/Digali dengan jemarinya)

Tuturan kalimbaun ma'pagu'gu tersebut bermakna 'tanah besar dibukanya' dan tuturan batu napaturu-turu bermakna 'bebatuan dipecahkannya'. Bagi masyarakat daerah Tana Toraja, tuturan kalimbaun ma'pagu'gu dan batu napaturu-turu menceritakan tentang kegigihan seseorang dalam mengolah usahanya di bidang pertanian dan tidak pernah putus asa, demi untuk memenuhi kebutuhan hidupnya. Tuturan tersebut memberi pesan bahwa seberat apapun pekerjaan yang kita lakukan akan berhasil jika dikerjakan dengan sungguh-sungguh. Tuturan kalimbaun ma'pagu'gu dan batu napaturu-turu tersebut memberi pesan tentang pekerjaan 
atau mata pencaharian masyarakat daerah Tana Toraja.

Selain bermatapencaharian sebagai petani, dalam tuturan kada tominaa ditemukan juga masyarakat daerah Tana Toraja yang bermatapencaharian sebagai peternak. Hal itu terungkap pada data berikut ini.

/Bala tedong marapuan/Bontong ma'lako-lakoan/Kayunna membua ringgi'/Sola menta'bi eanan

(/Kandang kerbaunya semakin banyak/Tersebar di mana-mana/Berbuahkan ringgit/Berbungakan harta benda)

Tuturan bala tedong marapuan tersebut bermakna 'kandang kerbaunya semakin banyak'. Tuturan bala tedong marapuan menceritakan tentang seseorang yang berternak kerbau untuk memenuhi kebutuhan hidupnya yang dimulai dari satu ekor namun hari demi hari semakin bertambah jumlah kerbau peliharaannya itu. Tuturan tersebut memberi pesan bahwa sekecil apapun yang kita kerjakan, jika itu dikerjakan dengan sungguh-sungguh, akan menghasilkan kesuksesan. Tuturan bala tedong marapuan memberi pesan tentang pekerjaan atau mata pencaharian masyarakat daerah Tana Toraja.

\section{Fungsi Pesan}

Dalam Kada Tominaa, terkandung pesan yang memiliki fungsi sebagai harapan dan nasihat. Pesan tersebut dapat dicermati pada kegiatan singgi dan kegiatan rampanan kapa. Pesan yang berfungsi atau bermakna harapan terdapat pada kegiatan singgi yang dapat dicermati pada kutipan berikut ini.

Dadi deatamo dao,/Kombongmi to palulungan/Manda' natakia' lemba'l Nasalungku bunga' lalan'/Naapan mengkidi-kidi/

(Maka jadilah ia dewa di atas/Menjadi pelindung mulia'//Erat dipegang bintang bertiga/Ditopang bintang

\section{penjuru /Dikerumuni bintang pen- erang)}

Tuturan manda' natakia' lemba' tersebut bermakna 'erat dipegang bintang bertiga', tuturan nasalungku bunga' lalan' bermakna 'ditopang bintang penjuru', sedangkan tuturan naapan mengkidi-kidi bermakna 'dikerumuni bintang penerang'. Tuturan manda' natakia' lemba', nasalungku bunga' lalan', dan naapan mengkidi-kidi merupakan bentuk harapan masyarakat daerah Tana Toraja agar orang yang telah meninggal itu diantar oleh malaikat menuju surga. Tuturan manda' natakia' lemba', nasalungku bunga' lalan', dan naapan mengkidi-kidi merupakan pesan untuk menyampaikan harapan-harapan masyarakat daerah Tana Toraja. Sementara itu, pada kegiatan rampanan kapa' 'pernikahan', dituturkan kata-kata harapan seperti dalam kutipan berikut ini.

/Den upa'napoupa'/Paraya nappaoraya/Anna lambi matua induk/Na dete'i banua karurungan

(/Semoga bahagia/Semoga selamat/

Seperti enau/Sampai usia tua)

Tuturan den upa'napoupa' tersebut bermakna 'semoga bahagia' sedangkan tuturan paraya nappaoraya bermakna 'semoga selamat'. Bagi masyarakat daerah Tana Toraja, tuturan den upa'napoupa' dan parayanappaoraya merupakan bentuk harapan agar rumah tangga yang dibentuk itu selalu diliputi rasa bahagia, anggota keluarga saling mengasihi dan menyanyangi, dan mengharapkan agar rumah tangga tersebut utuh. Tuturan den upa'napoupa'dan paraya nappaoraya merupakan bentuk tindak direktif yang berfungsi untuk menyampaikan harapanharapan masyarakat daerah Tana Toraja.

Contoh tuturan lain yang terekam sebagai harapan agar rumah tangga yang dibentuk melalui pernikahan segera mendapatkan keturunan dapat dicermati pada kutipan berikut. 
/Den upa' napoupa'/Paraya napoparaya/Anna mellolo rakka//Menta'bi taruno/

(/Semoga bahagia/Semoga selamat/ Sehingga bertunas batangnya/Berbunga tangkainya)

Tuturan den upa' napoupa', paraya napoparaya, anna mellolo rakka', menta'bi taruno tersebut bermakna 'semoga bahagia, semoga selamat, sehingga bertunas batangnya, berbunga tangkai-anya'. Tuturan den upa' napoupa', paraya napoparaya, anna mellolo rakka', menta'bi taruno bagi masyarakat daerah Tana Toraja merupakan harapan agar segera memiliki anak, karena anak adalah harta yang termulia dan merupakan generasi penerus dalam suatu keluarga. Tuturan tersebut merupakan bentuk direktif yang berfungsi untuk menyampaikan harapan-harapan masyarakat daerah Tana Toraja.

Selain pesan yang berfungsi sebagai harapan, dalam Kada tominaa terdapat pesan yang berfungsi sebagai nasihat. Pesan nasihat berupa nasihat dalam hubungannya dengan Tuhan. Pesan tersebut tercermin dalam tuturan kada tominaa pada kegiatan singgi berikut ini.

Natole/tumangke suru'/Tumetang passara'kasan/Suru'na rampanan kapa'/Sola passulean allo

(Sekali lagi ia /menyembah Tuhan/ Melakukan pemujaan/Beribadah dalam upacara perkawinan/Bersama bergantinya hari)

Tuturan tumangke suru' tersebut bermakna 'menyembah Tuhan' sedangkan tuturan tumentang passara' kasan bermakna 'melakukan pemujaan'. Tuturan tumangke suru' dan tumentang passara'kasan bagi masyarakat daerah Tana Toraja, merupakan bentuk nasihat agar seseorang melakukan hubungan dengan Tuhan dengan cara beribadah kepada Tuhan. Tuturan tumangke suru' dan tumentang passara'kasan merupakan bentuk tindak direktif yang berfungsi untuk menyampaikan nasihat.

Selain nasihat yang menceritakan tentang hubungan antara manusia dengan Tuhan, juga terdapat nasihat yang berhubungan dengan pekerjaan atau mata pencaharian. Pesan tersebut dapat ditemukan dalam tuturan kada tominaa berikut ini.

Suru'na /tengko tiranduk/Sola /ayoka panoto/Ma'doke-doke rangka'nal Ma'pasoan tarunona/Sitondon tindo bonginna sola mamma'karoenna

(Ibadah /mengolah tanah/Upacara / menanam bajak/Jari-jarinya bagaikan tombak/Jemarinya setajam linggis/ Jadilah sesuai mimpi-mimpi dalam tidurnya)

Tuturan tengko tiranduk tersebut bermakna 'mengolah tanah' sedangkan tuturan ayoka panoto bermakna 'menanam bajak'. Tuturan tengko tiranduk dan ayoka panoto bagi masyarakat daerah Tana Toraja merupakan bentuk nasihat agar seseorang itu rajin dan tekun dalam melaksanakan pekerjaan atau mata pencaharian, agar mendapatkan banyak rejeki, sehingga apa yang dicita-citakan akan tercapai karena hasil dari kerja kerasnya itu. Jika orang itu malas bekerja, maka rejeki itu tidak akan datang dan kesuksesan yang dicitacitakan juga tidak tercapai. Tuturan $t u-$ mangke suru' dan tumentang passara'kasan merupakan bentuk tindak direktif yang berfungsi untuk menyampaikan nasihat.

Nasihat lain dalam kaitannya dengan antarsesama adalah nasihat agar selalu melakukan hubungan yang baik dengan sesama. Hubungan yang dimaksud adalah berupa tegur sapa jika bertemu dengan orang lain. Pesan tersebut terdapat pada kegiatan batingberikut ini.

/To malute lako tau/Mabakko lako toratu/Ia ke sitammu lalanki'/Siduppa pallawanganki'

(Orang yang baik kepada orang lain/ Ramah kepada orang yang datang/ 
Jika kita bertemu/Saling berhadapan)

Tuturan to malute lako tau bermakna 'orang yang baik kepada orang lain' sedangkan tuturan mabakko lako to ratu bermakna 'orang yang ramah kepada orang lain'. Tuturan to malute lako tau dan mabakko lako to ratu bagi masyarakat daerah Tana Toraja, merupakan bentuk nasihat agar selalu melakukan hubungan yang baik dengan sesama, misalnya berupa bertegur sapa jika bertemu dengan orang lain. Terlebih jika ada orang datang bertamu ke rumah kita, sebaiknya disambut dengan wajah yang ramah dan tutur kata yang santun. Tuturan tumangke suru' dan tumentang passara'kasan dalam kada tominaa tersebut merupakan bentuk tindak direktif yang berfungsi untuk menyampaikan nasihat.

Paparan di atas menggambarkan fungsi pesan yang terdapat dalam tuturan Kada tominaa. Fungsi pesan tersebut pada hakikatnya juga merupakan fungsi tindak tutur. Oleh karena itu, makna pesan yang disampaikan melalui tuturan itu sejalan dengan fungsi tindak tutur yang dilakukannya. Searle (Schiffrin, 2007:64) menjelaskan bahwa suatu tuturan bukan sekadar pernyataan atau pertanyaan tentang informasi tertentu, tetapi tuturan tersebut merupakan suatu tindakan. Selanjutnya Searle (dalam Cummings, 2007:11; Levinson, 1986:240; Rahardi, 2009:17) juga menyebutkan lima jenis tindak tutur, yaitu (1) tindak tutur deklaratif, (2) tindak tutur representatif, (3) tindak tutur ekspresif,(4) tindak tutur direktif, dan (5) tindak tutur komisif. Pesan-pesan dalam tuturan kada tominaa daerah Tana Toraja memiliki fungsi tindak tutur. Fungsi tuturan tersebut dapat dikelompokkan menjadi dua, yakni fungsi ekspresif, yang meliputi: meminta maaf, mengungkapkan perasaan, sedangkan fungsi direktif, meliputi harapan dan nasihat. Rani, dkk. (2006:159) mengemukakan bahwa tindak tutur merupakan produk dari suatu kalimat dalam kondisi tertentu dan merupakan kesatuan terkecil dari komunikasi bahasa yang menentukan makna kalimat.

Pesan-pesan budaya yang diuraikan di atas merupakan isi komunikasi yang disampaikan melalui tuturan lagu. Pada dasarnya, pesan tersebut juga merupakan pesan dalam tindak tutur. Dalam hal ini, tindak tutur merupakan unit dasar komunikasi (Searle, 1983:21). Pandangan ini menyarankan bahwa terdapat serangkaian hubungan analitis antara makna tindak tutur dengan maksud penutur, maksud kalimat yang diujarkan, pemahaman mitra tutur, dan kaidah yang mengatur unsur-unsur bahasa. Karena itu, makna pesan-pesan yang disampaikan melalui tuturan itu sejalan dengan fungsi tindak tutur yang dilakukannya.

Paparan tersebut menggambarkan bahwa masyarakat Tana Toraja dalam kehidupan sehari-hari tampak pada hubungan yang harmonis dalam kehidupan bermasyarakat. Daldjoeni dan Suyitno (1986) menjelaskan bahwa dalam hidup di dunia ini manusia memiliki etika lingkungan yang tidak dapat dilepaskan dengan iman manusia beragama. Dalam etika tersebut, setiap manusia harus bertanggung jawab kepada Tuhan. Untuk menunjukkan tanggung jawab tersebut, masyarakat Tana Toraja selalu menjalankan ibadahnya sesuai dengan aturan dalam agama mereka masing-masing.

Sebagai makhluk ciptaan Tuhan, de Vos (Mardimin,1994) menyatakan bahwa manusia dijadikan menurut gambaran Tuhan. Karena itu, manusia harus tahu kepada Tuhannya yang dapat diwujudkan dengan cara selalu berbuat baik, jujur, menghormati sesama, dan tidak lupa selalu ingat kepada Tuhan dengan rajin beribadah. Selain itu, juga harus bertanggung jawab terhadap alam walaupun manusia mampu menguasai alam. 


\section{SIMPULAN}

Pesan yang terdapat dalam tuturan kada tominaa daerah Tana Toraja, meliputi (a) isi pesan yang dituturkan dalam kada tominaa daerah Tana Toraja, dan (b) fungsi pesan yang terdapat dalam tuturan kada tominaa daerah Tana Toraja. Isi pesan dalam kada tominaa daerah Tana Toraja dapat dikategorisasikan menjadi tiga ranah, yakni (a) tradisi budaya masyarakat daerah Tana Toraja, (b) hubungan sosial kemasyarakatan daerah Tana Toraja, meliputi hubungan saling mencintai antaranggota keluarga, dan hubungan saling peduli antarmasyarakat, (c) pekerjaan atau mata pencaharian masyarakat daerah Tana Toraja. Fungsi pesan yang terdapat dalam tuturan kada tominaa daerah Tana Toraja, meliputi (a) fungsi pesan dalam tindak ekspresif, dan (b) fungsi pesan dalam tindak direktif. Fungsi pesan dalam tindak ekspresif, berupa (a) meminta maaf, dan (b) mengungkapkan perasaan, sedangkan fungsi pesan dalam tindak direktif, berupa (a) harapan, (b) nasihat.

Hasil penelitian ini dapat memberikan masukan dan sumbangan pemikiran bagi pihak terkait dan berkompeten. Bagi guru, temuan penelitian ini dapat dijadikan sebagai bahan pendidikan karakter melalui pembelajaran bahasa dan sastra daerah Tana Toraja. Bagi pengembang kurikulum, temuan tersebut dapat dijadikan sebagai bahan pertimbangan dan acuan dalam menyusun kurikulum muatan lokal yang memanfaatkan kearifan lokal sebagai sumber pendidikan karakter bagi siswa sastra daerah.Bagi pemerintah, dapat dijadikan sebagai masukan untuk menentukan kebijakan dalam rangka pemertahanan dan pelestarian kada tominaa sebagai tradisi lisan masyarakat daerah Tana Toraja yang bermanfaat untuk menanamkan karakter bagi generasi muda. Bagi masyarakat, temuan ini dapat dijadikan pedoman dan penuntun dalam kehidupan bermasyarakat, berbangsa, dan bernegara.

\section{UCAPAN TERIMA KASIH}

Melalui bagian akhir dari artikel ini, penulis ingin menyampaikan ucapan terima kasih kepada berbagai pihak yang telah banyak memberikan kontribusi yang sangat signifikan demi terciptanya artikel ini. Artikel ini ditulis berdasarkan sebagian temuan penelitian disertasi yang berjudul "Ekspresi Metaforis dalam Tuturan Kada Tominaa Daerah Tana Toraja". Karena itu, penulis mengucapkan terima kasih kepada para pembimbing yang telah banyak memberikan arahan dan ilmunya kepada penulis: (1) Prof. Dr. H. Imam Syafi'ie, (2) Dr. H. Mujianto, M.Pd, dan (3) Prof. Dr. H. Imam Suyitno, M.Pd. Ucapan terima juga, penulis sampaikan kepada Dekan Fakultas Keguruan dan Ilmu Pendidikan dan Rektor Universitas Kristen Indonesia Toraja yang telah memfasilitasi penulis untuk menyelesaikan studi dan melakukan penelitan ini.

\section{DAFTAR PUSTAKA}

Adams, M. Kathleen. 2006. Art As Politics Re-Crafting Identities, Tourism, and Power in Tana Toraja, Indonesia. University of Hawai'i Pres.

Bogdan \& Biklen. 1990. Riset Kualitatif untuk Pendidikan. Jakarta: Depdikbud Proyek Pengembangan Pusat Fasilitas Bersama Antar-Universitas

Cummings, Louise. 2007. Pragmatik Sebuah Perspektif Multidisipliner. Diterjemahkan oleh Eti Setiawan, dkk. Yogyakarta: Pustaka Pelajar

Daldjoeni, N. dan Suyitno. 1986. Pedesaan, Lingkungan, dan Pembangunan. Bandung: Penerbit Alumni.

Koentjaraningrat. 1981. Kebudayaan Jawa. Jakarta: Balai Pustaka.

Levinson, Stephen. 1986. Pragmatics.London: New York: Cambridge Universit Press

Mardimin, Johanes. 1994. Jangan Tangisi Tradisi: Transformasi Budaya Menuju Masyarakat Indonesia Modern. Yogyakarta: Kanisius. 
Pamungkas, Sri. 2012. Bahasa Indonesia dalam Berbagai Persfektif. Yogyakarta: C.V Andi Offset

Rahardi, Kunjana. 2009. Sosiopragmatik. Yogyakarta. Erlangga

Rani, Abdul. 2006. Analisis Wacana: Sebuah Kajian Bahasa dalam Pemakaian. Malang. Banyumediu

Ricoeur, Paul. 2003. Filsafat Wacana: Membelah Makna dalam Anatomi Bahasa. Diterjemahkan oleh Musnur Hery. Yogyakarta: IRCiSod

Suyitno. Imam. 2010. Mengenal Budaya Etnik melalui Pemahaman Wacana Budaya. Malang: A3 (Asah, Asih, Asuh)

Schiffrin, Deborah. 2007. Ancangan Kajian Wacana. Diterjemahkan oleh: Unang. dkk. Yogyakarta: Pustaka Pelajar
Sumaryono. 1995. Hermeneutika: Sebuah Metode Filsafat. Yogyakarta: Kanisius

Saryono, Djoko. 2006. Pergumulan Estetika Sastra di Indonesia. Malang: Pustaka Kayutangan

Searle, John R. 1983. Speech Acts: An Essay in The Philosophy of Language. Cambridge: Cambridge University Press.

Sikki, Muhammad dkk. 1986. Struktur Sastra Lisan Toraja. Jakarta: Depdikbud

Snijders, Adelbert. 2004. Antropologi Filsafat: Manusia Paradoks dan Seruan. Jogyakarta: Kanisius.

Wahab, Abdul. 1991. Isu Linguisik: Pengajaran Bahasa dan Sastra. Surabaya: Airlangga University Press 